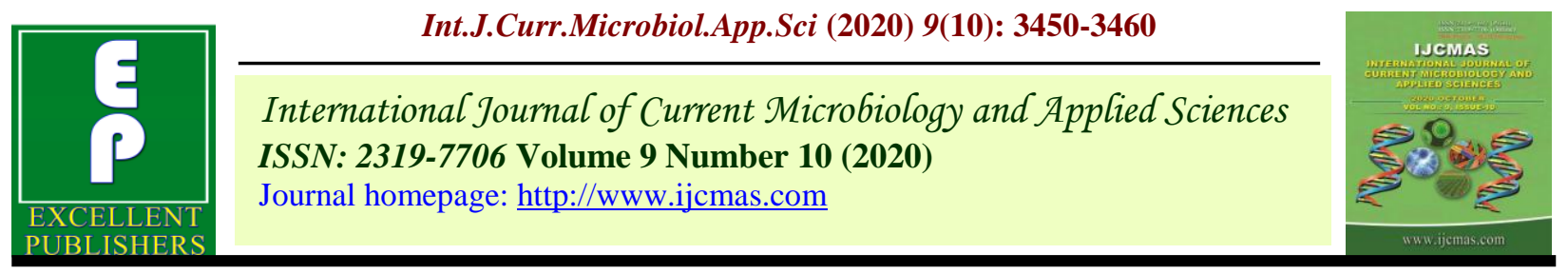

Original Research Article

https://doi.org/10.20546/ijcmas.2020.910.398

\title{
Opinion, Reasons and Benefits of Joining Self Help Groups in Tribal Sub Plan Region of Rajasthan-An Evaluative Study
}

\author{
Satyveer Singh Meena* \\ Institute of Agri Business Management, Swami Keshwanand Rajasthan Agricultural \\ University, Bikaner. Rajasthan, India \\ *Corresponding author
}

A B S T R A C T

Keywords

SHGs, Benefits, Members, Support, Activities, Opinions and Reasons

Article Info

Accepted: 26 September 2020 Available Online: 10 October 2020

\begin{abstract}
This paper explained about the benefits of joining SHGs by the members, factors responsible for success of the SHG, members need fulfilled internal loan facility, purposes of loans, repayment of loan and opinion about the performance of the SHG. Majority of members and villages were benefited by joining of SHGs. Specifically they were benefited from the various schemes and support activities of their SHG and support organizations. SHGs have provided better support to their families, easy availability of loans and increase in the savings for future. SHG also give support to establish business to support of their livelihood. The review of existing studied suggests that members can benefit in different aspects by joining of SHGs. As majority of villages have reported benefited from SHGs activities so more awareness should be carried out for SHG creation. SHG has been instrumental in creating easy credit availability for the members for their family support so wide spread of this concept is required in TSP region. SHGs are highly beneficial for eradication of poverty from the TSP region of Rajasthan.
\end{abstract}

\section{Introduction}

Poverty means those people who have nothing, whose lives are in constant hazard due to the shortage of all basic resources that are required for their survival. In broadspectrum, excessive poverty means extreme deprivation i.e. deprivation of all basic amenities of life. It is seen that along with the urbanization and modernization people met with different forms of poverty and every definition related to poverty also changes with the inclusion of new dimensions. Eradication of poverty is the main purpose of planning in
India from the inception of planning periods and NITI Ayog. Poverty has global presence and varied genesis and dimensions. It does not mean only human or income poverty but it also covers deprivation of human dignity caused by vulnerability to social and cultural shocks. Development Economics, till 1970s was considered that the "Trickle Down Effect" of growth oriented GNP will help to eradicate poverty gradually (Mansuri, 2010).

In recent years improving the situation of women and rural household through literacy, skill development and enhancing income 
generating capacity by way of more gainful employment on one hand coupled with the 'empowerment', through right to use to information, economic autonomy resulting from revenue generating activities and combined action on the other hand have become focal point of strategies for women and rural households' growth. Today Selfhelp groups (SHGs) play a major role in poverty alleviation in rural India. An increasing number of deprived people in a series of parts of India are members of SHGs and are keenly engaged in savings and credit, as well as in other activities eg. Income generation, natural resources management, literacy, child concern and nutrition, etc. The SHG system has proven to be very appropriate and helpful in offering women the possibility to break away gradually from exploitation and isolation. Nearly all main donor agencies support SHGs in India in one mode or another and a lot of success stories are available, unfolding how membership in a SHG changed the life of a particular human being or group for the improvement. Lots of NGOs are encouraging the SHG instrument and linking it to a variety of other development interferences. Whereas there is sufficient evidence that the SHG approach is a very successful, efficient and related tool for organizing and empowering the poor, do arise with design, growth and introduction of programmes to encourage Income-Generating Activities (IGAs) that will generate adequate, sustainable and regular income (Saravanan, 2016).

A SHG is a group of about 10 to 20 people from a uniform class, who come jointly for addressing their frequent troubles. They are promoted to create voluntary thrift on a continuous basis. They used the pooled resource to create tiny interest bearing loans to its members. The process helps them absorb the fundamentals of financial intermediation, including prioritization of needs and wants, setting terms and conditions and maintaining the books of accounts. This regularly develops financial control in all of them. They are also trained to handle resources of an extent that is far beyond their individual capabilities. The SHG members commence to appreciate that resources are limited and have a cost. Once the grouping shows this grown-up financial behaviour, banks are encouraged to build loans to the SHG in certain multiples of the accumulated savings of the SHG. Self help groups are compulsory to defeat mistreatment, develop self-confidence for the financial self-reliance of rural community, mainly among women who are frequently indistinguishable in the social structure.

\section{Formation of Self Help Groups}

There are three stages in SHG evolution.

Group formation

Capital formation through revolving fund and skill development

Income generating activities

\section{Scenario of Self Help Groups}

It is informative to contrast the SHGs with other small groups set up under the 'Grameen model' based on solidarity groups or JLGs (as it emerged in Bangladesh and spread throughout the world) where groups of women are in the same way brought mutually to access loans and other financial services.

India has adopted the Bangladesh's model in a modified shape. To alleviate the poverty and to make powerful the women, the microfinance is emerging as a powerful mechanism in the new economy. With accessibility of micro-finance, self-help groups (SHGs) and credit management groups have also started in India. So the SHG movement has spread out in India. 
In the study of Sukhbir (2007) NABARD has been playing the responsibility of propagator and catalyst by providing favorable course of action in surroundings, training and capacity building besides extending financial assistance for the strong growth of the SHG linkage programme over the years.

Total number of functioning SHGs in Rajasthan was 264119, out of which 98107 SHGs financed by banks as on 31 March, 2016. Loan distributed by public sector banks under SHG-Bank linkage programme in Rajasthan was`4832.96 lakhs in 2016-17.

\section{SHG in Tribal Sub Plan Region}

Tribal communities enjoy traditional leadership. However, the SHG movement is still very weak in the Tribal areas. There are many reasons for this. There is demand for credit across the households and districts, which was met by moneylenders, relatives and friends. There is a space for micro finance institutions like SHGs and MFIs

Not many households have interface with micro-finance institutions like SHGs. Wherever, SHGs are found, most are defunct too, especially created by government departments. These ICDS/ DRDA group was of very poor quality. These groups are poorly formed.

Interest rates are high for moneylender's loan. MFI interest rates are also not low. Here there are two issues- one using micro-finance for poverty alleviation and second considering micro-finance as a business. Today it is mainly the later than the former. Poverty cannot be eradicated with 24 percent rate of interest even if collateral is not taken. In the SHG movement savings are the collaterals.

There are many organizations which is working for promotion of SHGs in TSP region like, NGOs, ICDS through DWCD, NRLM (earlier SGSY) through RGAVP, NGOS and by others, DPIP, NABARD-SHGBLP through NGOs and some others are promoted by watershed development, literacy mission, RCDF, forest, watershed development, literacy mission, RCDF, forest through NGOs and cooperatives. The major players in Promotion are ICDS, Tribal Area Development department, NRLM and NGOs. (Joshi et al., 2010).

As per CMR 2007 report estimated SHGs in tribal region of Rajasthan are as follows:

As mentioned in above table the total number of SHGs, the highest numbers of SHGs were in Udaipur district, followed by Banswara, Chittorgarh, Dungarpur and Rajsamand district. The highest number of SHGs was promoted through ICDS/DWCD in Rajasthan as well as in TSP region.

\section{Review of Literature}

Brody et al., (2015) ESHG have positive effects on women's economic and political empowerment, as well as social empowerment - such as, women's family size decision-making power and social mobility. There is no quantitative evidence to indicate positive effects on women's psychological empowerment. However, the qualitative studies suggest that women participating in ESHG perceive themselves as psychologically empowered. ESHG with a training component, such as financial and business education or life skills training, have a larger effect than programs that do not involve training. Important mechanisms which facilitate empowerment are gaining financial skills (economic empowerment); gaining the capability to speak in front of others, access to household decision-making (psychological empowerment); improved networks and the experience of mutual 
support from and solidarity with fellow group members (social empowerment); and access to wider social participation combined with an increased understanding of political contexts and individual rights (political empowerment). Vinodhini and Vaijayanthi (2016) focused on the wages for women empowerment and reduction of poverty through self-help group. They have contributed by developing their social and economic status and empower women by increasing their income, expenditure and saving habits. The key reasons for the success of SHGS were its links with the poor people, its innovative practices, its capacity to enable people's participation building at different levels between stakeholders. They have developed self-confidence and independence among rural women, which in turn increased the livelihood of the rural people. Naik and Rodrigues (2017) concluded that Socioeconomic empowerment has been considered significant for overall development. Women's empowerment is evidently necessary for escalating socio-economic condition of the women in the society. The SHGs enabled women to aware about their rights, entitlements, taking part in various development programs and economic activities for their substantial development. Thus, SHGs made noteworthy impact on women empowerment.

Kumar et al., (2018) suggested that the group heterogeneity directly predicts the effectiveness of women's self-help groups and it is fully transmitted through group structure and process to positively predict the effectiveness of the women's self-help groups. The group structure and process is found to be a full mediator between group heterogeneity and group effectiveness. The predictive accuracy of the model is found to be high. The findings have implications to bring in more diversity in members castes, education, and their reasons for joining women's self-help groups at the formation stage and variations in members' skills and expertise at the performing stage of the groups. The members' awareness on group norms and trust in financial transactions, and leadership styles together with cooperation and cohesion among members, transparency in financial transactions, group attendance, and networking with the bank and the federation foster the effectiveness of women's self-help groups.

\section{Materials and Methods}

The present study includes descriptive research approach used to test the hypotheses and present conclusions from data analysis. The present study uses quantitative approach of problem solving.

\section{Collection of Data}

For achieving the objectives of the study and to carry out the analysis, both primary as well as secondary data were collected:

\section{Primary data source}

For the present research, primary data was collected through structured questionnaire by personal contact with SHG members.

\section{Secondary data source}

For the current study, secondary data was collected through books, periodicals, journals, web portals, research papers, and case-study, articles, and newspapers. Online directories like EBSCO, indiastat and Google Scholar websites were also very helpful.

\section{Sampling design}

For this study, multistage stratified random sampling and judgmental sampling were used. 
Population: ICDS promoted SHGs were selected by researcher because as per Rajasthan Micro Finance report March 201314, out of ICDS, NRLM (earlier SGSY), NABARD-SHG-BLP, DPIP and others, the highest number of SHGs were promoted in Rajasthan by ICDS $(2,31,212)$.

Five districts come under Tribal Sub Plan region viz. Udaipur, Dungarpur, Banswara, Pratapgarh and Sirohi. Researcher selected one tehsil from each district on the basis of random sampling (lottery method).

For primary data collection, judgmental sampling was used to select the SHGs which were established at least four years ago. Later the sample SHGs were selected on the basis of simple random sampling (lottery method). Six SHGs were selected randomly from every tehsil, 10 members were selected randomly from each SHG.

Sample Size: Due to the constraint of data availability of SHGs; cost and time limitation of the present study, 300 SHG members selected for the survey.

Research area: The study was conducted in Tribal Sub Plan (TSP) region of Rajasthan which includes Udaipur, Dungarpur, Banswara, Pratapgarh, Sirohi districts of Rajasthan.

Selection of tehsils: One tehsil from every district was selected randomly. 5 SHGs selected from each tehsil and members are selected randomly from each tehsil.

\section{Data analysis}

In this section researcher explained about the benefits of joining SHG on their village, factors responsible for success of the SHG, members need fulfilled internal loan facility and purposes of loans etc.

\section{Villages benefitted from the SHG}

From the point of different village benefit of joining SHG the respondent data were shown in figure-1.

Figure 1 analysis concluded that majority of village (95 percent) have been benefited from SHG activities and only 5 percent villages have not been benefited from joining of SHG. So the impact of joining SHG is growing rapidly in the region.

\section{Ways by which SHG benefited the village}

The respondents were asked about the ways by which SHG benefited the village. The data so obtained about the ways by which SHG benefited the villages are shown in figure 2 .

Figure 2 revealed the fact that majority of SHG members are benefited by the easy credit availability (53 percent) from SHG followed by women empowerment (26 percent), mutual cooperation among members of the group (20 percent) and awareness creation (1 percent). So on the basis of above statistics members want more focus on easy credit availability form SHG.

\section{Factors responsible for the success of SHGs}

Respondents have been asked about the factors responsible for success of SHGs. The responses generated are summarized in factors' rank in table 4.

Table 4 shows that majority of SHG members believe that efficient leadership and support from promotion agencies are the most important factors responsible for the success of SHG. Other important factors contributing the achievements of SHG include active support of SHG member, regular saving habit of members, proper maintenance of accounts and regular SHG meeting. 
Table.1 Details about the SHG promoting agencies in Rajasthan

\begin{tabular}{|c|c|c|}
\hline Agency & Scheme/ Project & Remarks \\
\hline DWCD & No specific scheme & $\begin{array}{l}\text { Groups are organised by Anganwadi } \\
\text { workers and Sathins }\end{array}$ \\
\hline $\begin{array}{l}\text { Department of } \\
\text { Rural } \\
\text { Development }\end{array}$ & 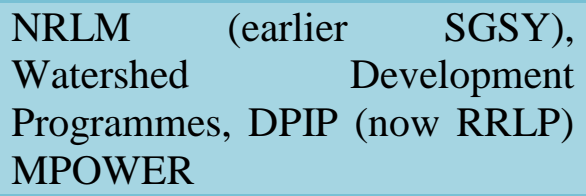 & $\begin{array}{l}\text { Groups comprising of mostly BPL } \\
\text { households- inclusive of co-opted from } \\
\text { NGOs following the norms of } \\
\text { "Panchasutra" }\end{array}$ \\
\hline $\begin{array}{l}\text { NABARD and } \\
\text { Banks }\end{array}$ & SHG-Bank Linkage Programme & $\begin{array}{l}\text { Through NGOs, RRBs and } \\
\text { Cooperatives. }\end{array}$ \\
\hline Cooperatives & & $\begin{array}{l}\text { The cooperatives have very recently } \\
\text { started forming SHGs }\end{array}$ \\
\hline $\begin{array}{l}\text { Civil Society } \\
\text { Oraganisations }\end{array}$ & $\begin{array}{l}\text { With support from Donor } \\
\text { agencies (such as Sakh Se Vikas } \\
\text { of SRTT) and Govt. programmes }\end{array}$ & $\begin{array}{l}\text { Groups promoted by NGOs under } \\
\text { Govt. sponsored programmes are } \\
\text { often reported by both }\end{array}$ \\
\hline Others & $\begin{array}{l}\text { Forest } \\
\text { Department of } \begin{array}{r}\text { Department, } \\
\text { Industries } \\
\text { (under cluster development } \\
\text { programme) }\end{array}\end{array}$ & \\
\hline
\end{tabular}

Source: http://www.cmfraj.org/MicrofinanceReport2012.pdf by Bhargava, 2011

Table.2 SHGs in tribal region of Rajasthan

\begin{tabular}{|l|c|c|c|c|c|}
\hline \multicolumn{1}{|c|}{ Districts } & ICDS/DWCD & SGSY & DPIP & Others & Total \\
\hline Banswara & 5375 & 2875 & - & 500 & 8750 \\
\hline Rajasamand & 2500 & 1000 & 3250 & - & 6750 \\
\hline Chittorgarh & 6625 & 1250 & - & 375 & 8250 \\
\hline Udaipur & 5625 & 2750 & - & 1750 & 10125 \\
\hline Dungarpur & 3125 & 3625 & - & 1250 & 8000 \\
\hline
\end{tabular}

Source: Estimated from CMR, 2008, Status of Micro Finance in Rajasthan

Table.3 List of selected tehsils with number of members

\begin{tabular}{|l|c|}
\hline \multicolumn{1}{|c|}{ Strata [District (Tehsil)] } & Sample size (Members) \\
\hline Banswara (Ghatol) & 60 \\
\hline Dungarpur (Dungarpur) & 60 \\
\hline Pratapgarh(Pratapgarh) & 60 \\
\hline Sirohi (Aburoad) & 60 \\
\hline Udaipur (Salumbar) & 60 \\
\hline Total & 300 \\
\hline
\end{tabular}

Source: Author's compilation 
Table.4 Factors responsible for the success of SHGs

\begin{tabular}{|l|c|c|}
\hline Factors responsible for the success of SHGs & Rank & Mean \\
\hline Efficient leaders & 1 & 2.72 \\
\hline Support of promotion agency & 2 & 3.08 \\
\hline Active support of SHG member & 3 & 3.38 \\
\hline Regular saving habit of members & 4 & 3.40 \\
\hline Proper maintenance of accounts & 5 & 3.96 \\
\hline Regular SHG meeting & 6 & 4.43 \\
\hline
\end{tabular}

Source: Author's compilation

Table.5 Details of amount of loan taken by respondents

\begin{tabular}{|l|c|c|}
\hline Loan Amount & Frequency & Percentage \\
\hline up to 5000 & 33 & 11 \\
\hline$>5000-10000$ & 177 & 59 \\
\hline$>10000-15000$ & 51 & 17 \\
\hline$>15000-20000$ & 30 & 10 \\
\hline$>20000$ & 9 & 3 \\
\hline
\end{tabular}

Source: Primary Data

Table.6 Purpose of loan

\begin{tabular}{|l|c|c|}
\hline \multicolumn{1}{|c|}{ Purpose of loan } & Frequency & Percentage \\
\hline Productive purpose & 69 & 23 \\
\hline Starting new venture & 42 & 14 \\
\hline Health purpose & 0 & 0 \\
\hline Education & 0 & 0 \\
\hline Children Marriage & 21 & 7 \\
\hline Agriculture purpose & 24 & 8 \\
\hline Other & 144 & 48 \\
\hline
\end{tabular}

Source: Primary Data

Fig.1 Villages benefitted from the SHG

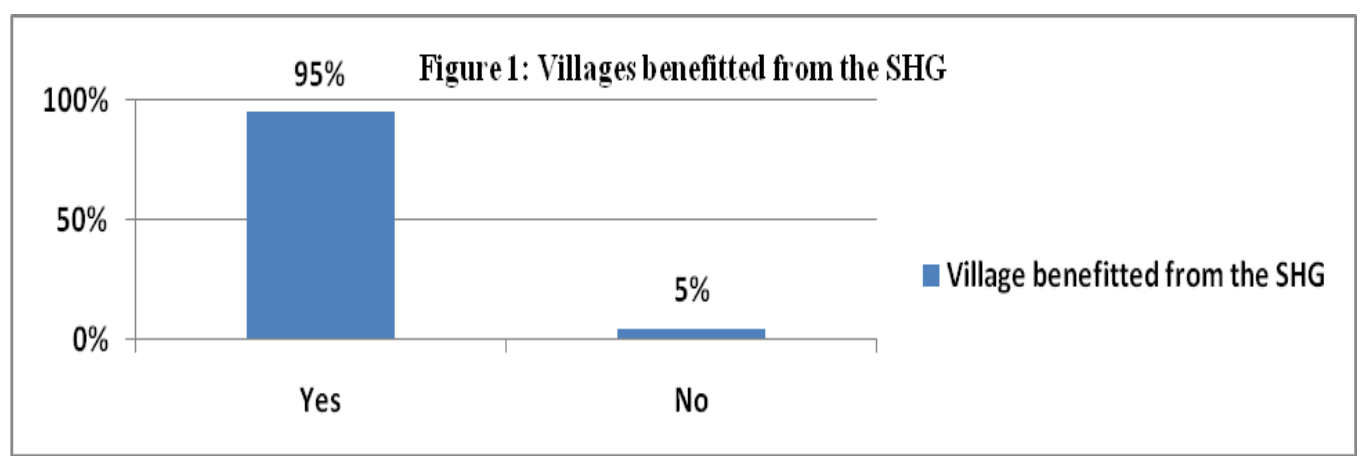

Source: Author's compilation 
Fig.2 Ways by which SHG benefited the village

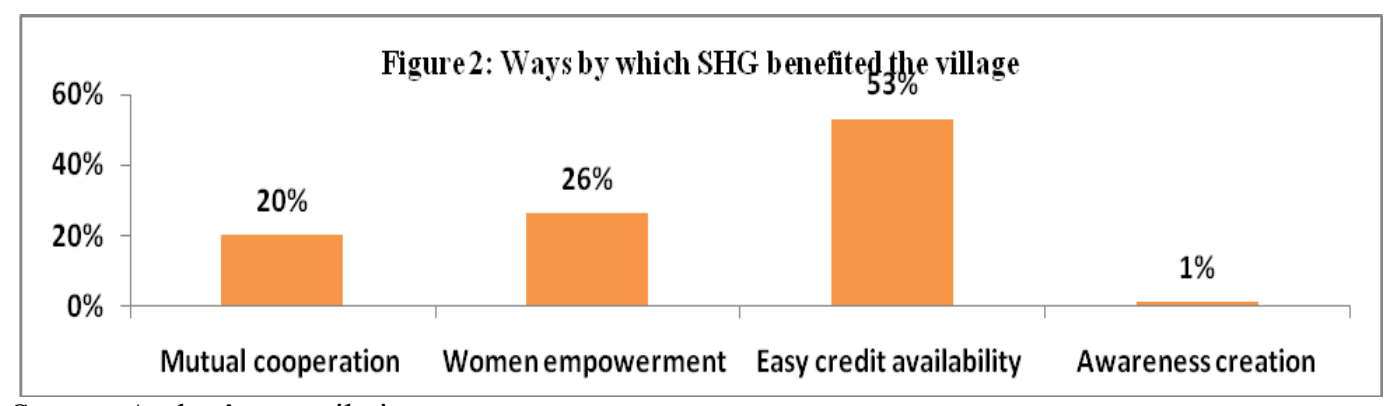

Source: Author's compilation

Fig.3 Members' needs fulfilled by SHGs

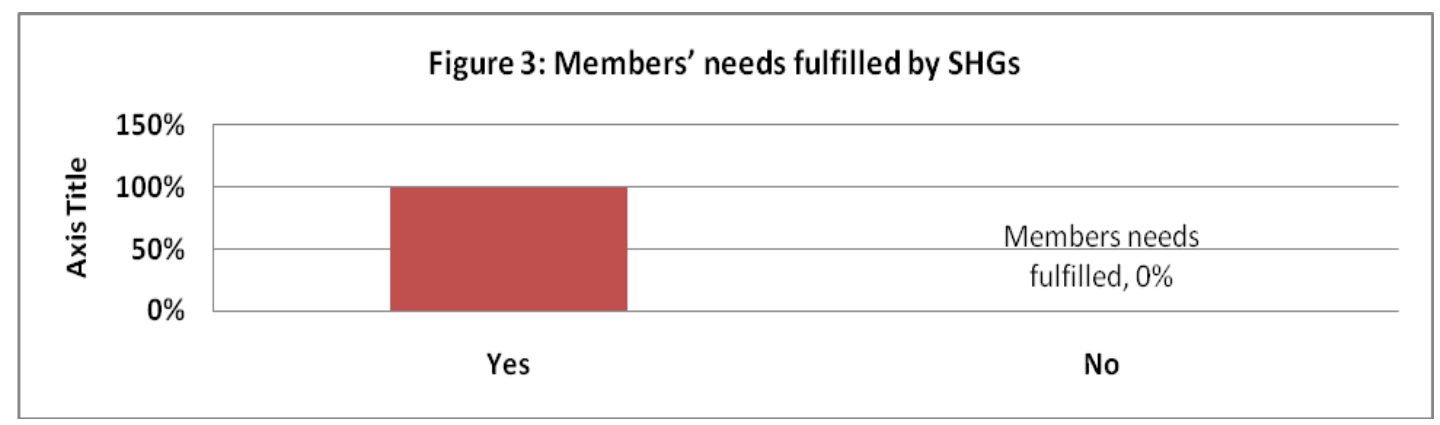

Source: Primary Data

Fig.4 Reasons for joining SHG

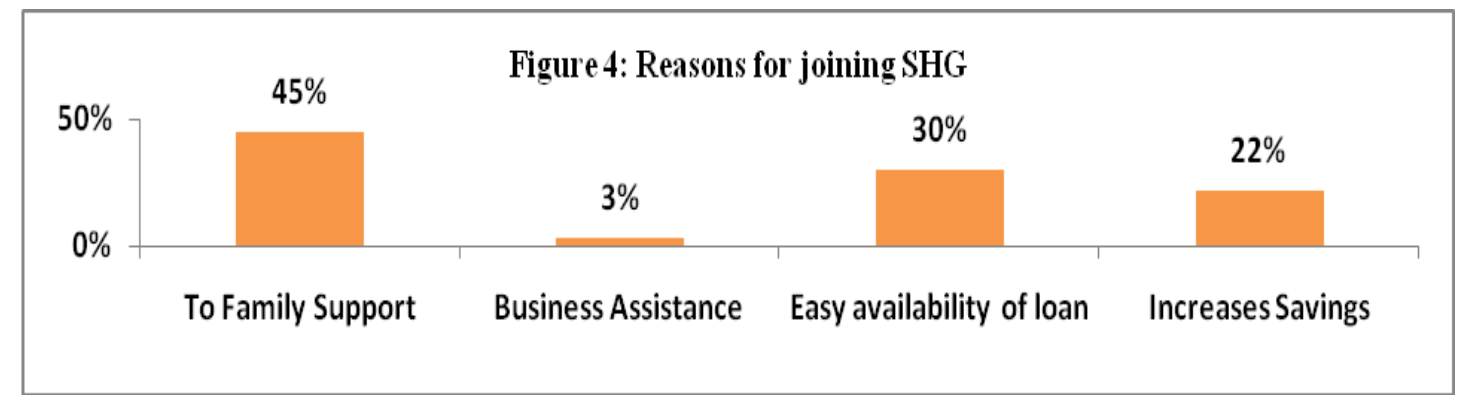

Source: Primary Data

Fig.5 Internal loan for SHG members

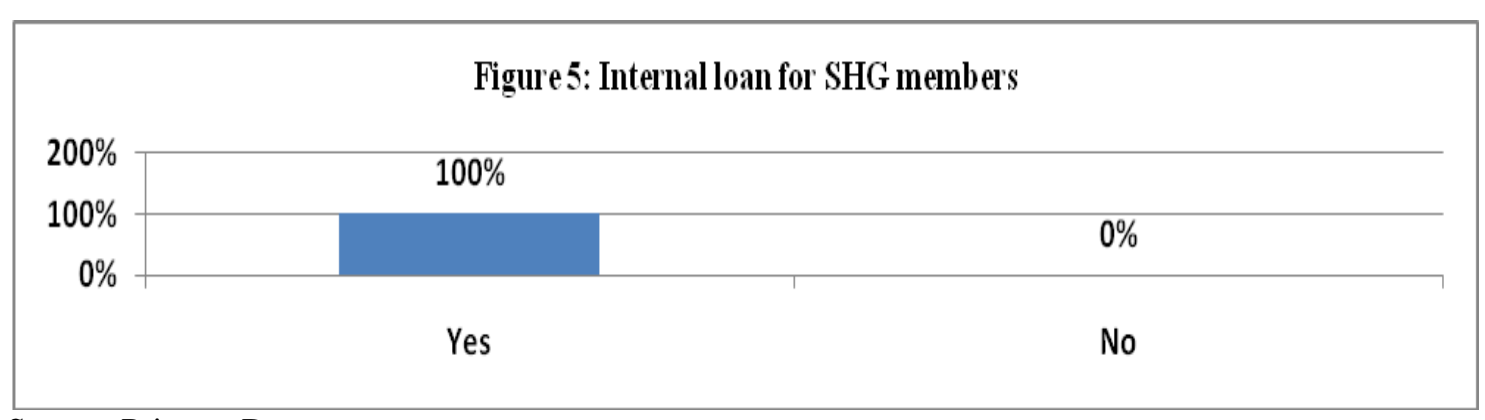

Source: Primary Data 
Fig.6 Repayment of loan amount

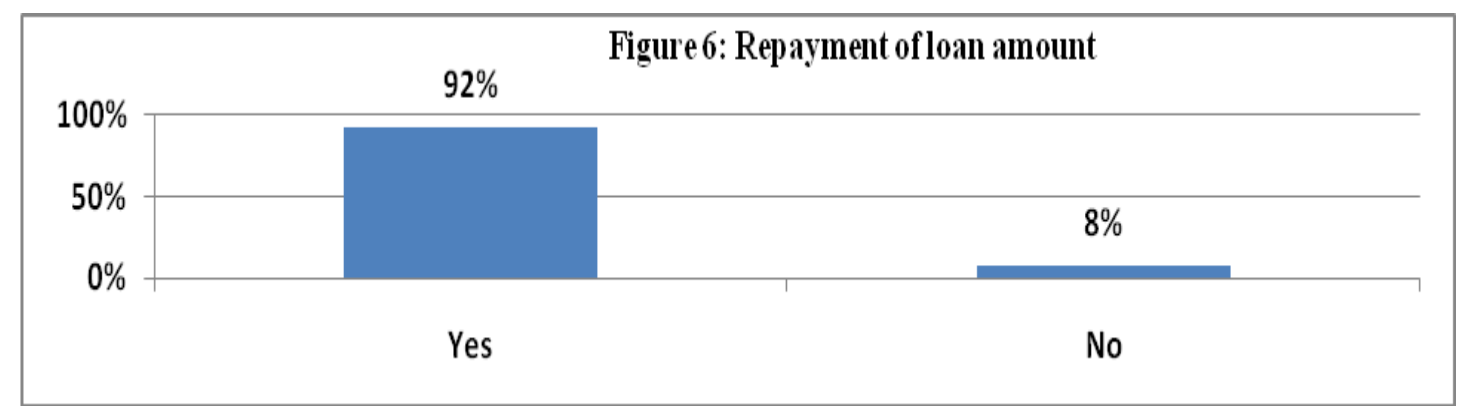

Source: Primary Data

Fig.7 Opinion about the Performance of SHG

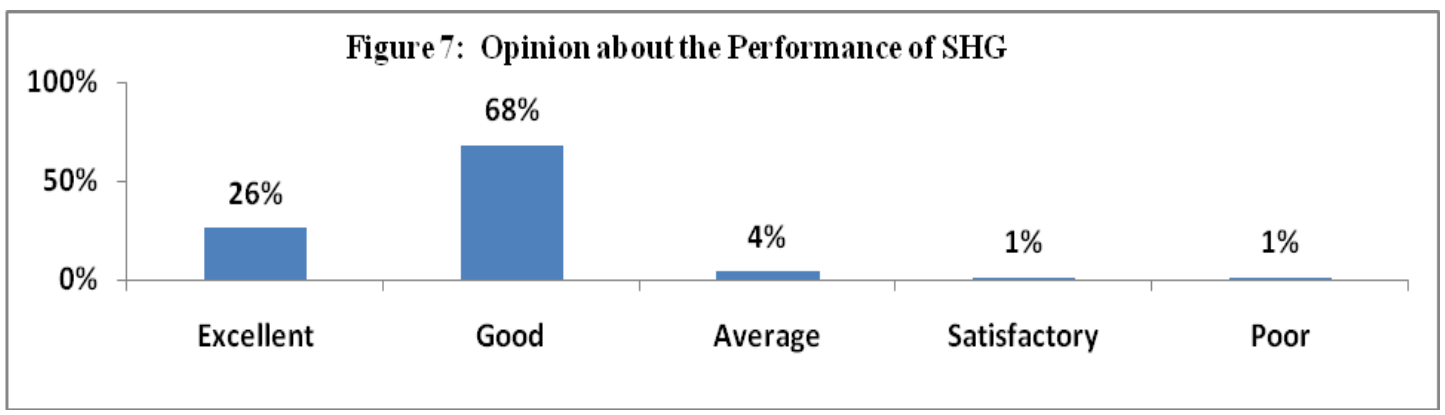

Source: Primary Data

\section{Members needs fulfilled by the SHGs}

In questionnaire respondent were asked about their needs fulfilled by the SHGs. The members' responses presented in Figure 3.

Figure 3 revealed the fact that SHG members strongly believed that they are benefited from the various schemes and support activities of their SHG and support organizations.

\section{Main reasons for joining SHG}

The questionnaire included a question asking the main reason for joining SHG. The responses are summarized in figure 4.

Figure 4 concluded that majority of SHG members (45 percent) join the SHG to provide better support to their families, easy availability of loans (30 percent) and increase in the savings for future (22 percent). SHG also give support to establish business to support of their livelihood.

\section{Loan benefits to respondents}

In this section respondents were asked about the internal loan for members from SHG, details of loan, purpose of loan, repayment of loan amount and performance of SHG.

\section{SHG provide internal loan for Members}

The respondents were asked about internal loan facility to them from SHG. The data so obtained about internal loan for members are shown in figure 5.

Figure 5 show that majority of SHG members believe that their SHG provide internal loan facilities for their members. 
Details of amount of loan taken by respondents

The amounts of loan were classified in five categories. The responses are summarized in the table 5 .

Table 5 concluded that majority of SHG members taken a loan amount of 5-10 thousand rupees. However, 17 percent of members agreed to avail the loan facility for $10-15$ thousand rupees, 10 percent of members agreed to avail the loan facility for 15-20 thousand rupees and 3 percent of members agreed to avail the loan facility more than 20 thousand rupees.

\section{Purpose of loan}

Respondents were asked about the purpose of loan. The responses are presented in table 6 .

Table 6 revealed the fact that the most popular reason for applying for the loan is for productive purpose followed by starting new business, agriculture purposes, and children marriage. 48 percent members take loan for other purposes.

\section{Timely repayment of loan amount}

To have an idea about the respondents' repaying loan on time a question was asked about it. The responses are presented in figure 6.

Figure 6 shows that majority of SHG members (92 percent) agreed for the timely payment of their loan amount back to SHG. While 8 percent told that they are unable to pay loan on time

\section{SHG performance}

To have an idea about the SHGs performance. Therefore, the most prominently used likert scale has been used here. Responses are presented in Figure 7.

From the figure 7 , it can be concluded that majority of SHG members rate 'good' about the performance of their SHG (68 percent). 26 percent of respondent even rank 'excellent' to their SHGs. However, still there are 4 to 5 percent of members those are not satisfied with the performance and function of SHG.

In conclusion the based on the major findings of the research, the following conclusion has been drawn from member's perspective: Majority of the Self Help Group member interviewed indicated that, they have benefited from the being part of Self Help Group. Notable among the benefits are easiness in accessing credit, empowerment of members and increase mutual cooperation. Based on this, majority of the Self Help Group members ranked the performance of their groups as good especially efficient leadership and support of promoting agency. Study revealed that member's needs were fulfilled by their SHGs and internally they were getting loan for productive purposes and for starting new venture specially. The important reason for joining SHG was to support to their family.

\section{References}

Bhargava, P. (2011). Rajasthan Microfinance Report, Centre for microfinance, Retrived from http://www.cmfraj.org/MicrofinanceR eport2012.pdf dated 16-02-2015.

Brody, C., De Hoop, T., Vojtkova, M., Warnock, R., Dunbar, M., Murthy, P., \& Dworkin, S. L. (2015). Economic Self-Help group programs for improving women's Empowerment: a systematic review. Campbell Systematic Reviews, 11(1), 1-182.

CmF Report (2008), Center for Microfinance, 
Jaipur. Retrieved on June 30, 2016 from http://www.cmfraj.org/aboutcmf.html.

Joshi V., Singh S., and Kumar M. S., (2010): "Tribal development framework" State Project Support Unit-RRLP, Panchayat and Rural Development Department, Government of Rajasthan, Jaipur 1-105.

Kumar, S. (2011), The role of microfinance in reducing poverty of women in India, People's Journal of Management. Pp. 57-61.

Lakshmi, K. (2019) Womenee s Empowerment through Self Help Groups

Mansuri, B. B. (2010). Micro financing through Self Help Groups-A Case Study of Bank Linkage Programme of NABARD. APJRBM, Sri Krishna International Research \& Educational Consortium, 1(3), 141-150

Number of SHGs and amount of saving by Regional Rural Banks (RRBs) and Cooperative banks under SHG-Bank linkage programme in the year 201516. (2017, Oct 13) retrieved from (https://www.indiastat.com/table/s ocialandwelfareschemes/27/selfhelpgr oups/18063/958512/data.aspx)

Naik, M. and Rodrigues, A. (2017). Women Empowerment Through Self Help Groups: Realities And Challenges, IOSR Journal Of Humanities And Social Science (IOSR-JHSS), Vol. 22(6), Ver.12, 01-09.

Kumar, R., Suar, D., and Mishra, P. (2018). Characteristics for the effectiveness of women's self-help groups in bihar. VOLUNTAS: International Journal of Voluntary and Nonprofit Organizations, 29(6), 1283-1299.

Saraswathy, A., Porkodi, S., and Buvaneswari, M. (2009). Micro Finance in Krishnagiri District, Indian Journal of Marketing, 39(5), 47-57.

Saravanan, M., (2016): "The impact of Self Help Groups on the Socio-Economic development of rural household women in Tamilnadu- A study". International Journal of ResearchGranthaalayah: A knowledge Repository. Vol. 4(7), 22-31. DOI: 10.5281/zenodo.59360.

Sarania, R. (2015). Impact of Self-Help Groups on Economic Empowerment of Women in Assam. International Research Journal of Interdisciplinary \& Multidisciplinary Studies, 1(1), 148159.

Sukhbir S., (2007) "Towards inclusives rural financial services - Microfinance in India", Edited by Sangita Kamdar, Microfinance, Self-employment and poverty alleviation, Himalaya Publishing House, p. 61.

Sunny and Pereira, (2011), Self-Helpf Groups and Poverty Alleviation", International Journal of Business Management, Economics and Information Technology, Vol.3, No.1, 81-90.

Vinodhini R.L. and Vaijayanthi P. (2016), Self-Help Group and Socio-Economic Empowerment of Women in Rural India" Indian Journal of Science and Technology, Vol. 9(27), 1-5.

\section{How to cite this article:}

Satyveer Singh Meena. 2020. Opinion, Reasons and Benefits of Joining Self Help Groups in Tribal Sub Plan Region of Rajasthan-An Evaluative Study. Int.J.Curr.Microbiol.App.Sci. 9(10): 3450-3460. doi: https://doi.org/10.20546/ijcmas.2020.910.398 